\title{
Novos tempos, novos rumos
}

Anselmo Gomes de OLIVEIRA; Dâmaris SILVEIRA
As políticas públicas na área da Saúde no Brasil têm estimulado indústrias, profissionais e usuários do Sistema Único de Saúde a uma tomada de posição pró-ativa e mais indagadora. Ao mesmo tempo em que há uma busca por produtos inovadores, há uma valorização das práticas tradicionais, complementares e alternativas para prevenção e tratamento de doenças. Essa dicotomia, filosófica, cultural e cientificamente interessante, permite uma vasta rede de opções e pode estimular a oferta de produtos e serviços com eficácia, qualidade e segurança garantidas, favorecendo o paciente e usuário de produtos e serviços para a saúde.

As Ciências Farmacêuticas, com todas as nuances das áreas que representa, é então uma fonte inesgotável de oportunidades, novas ideias e novas tecnologias. No Brasil, os farmacêuticos têm tido oportunidade, tanto no setor público quanto no privado, de estar na vanguarda da Assistência Farmacêutica, na Pesquisa \& Desenvolvimento de novos produtos para a saúde, na formulação e aplicação da legislação na área. E o profissional farmacêutico que possuir as competências requeridas nessas áreas pode usufruir de uma carreira produtiva, estimulante e de impacto na Saúde Pública.

Assim, seria preciso repensar a educação farmacêutica no Brasil, conhecer qual o impacto das mudanças ocorridas nos últimos 10 anos e saber se o profis- sional que chega ao mercado de trabalho está apto para desempenhar as variadas funções que o campo tão amplo e ao mesmo tempo tão especializado das Ciências Farmacêuticas lhe proporciona.

O periódico Infarma está no seu $25^{\circ}$ volume. São 25 anos de trabalho divulgando as pesquisas e as realizações científicas dos profissionais da área farmacêutica, no País. Nesse momento, numa evolução natural, chega reformulado, mais amadurecido em sua concepção e ampliando sua proposta. A partir desse número, passa a ser publicado exclusivamente por meio eletrônico, com o título Infarma - Ciências Farmacêuticas. Deixa de ser um encarte da Revista Pharmacia Brasileira e passa a ter identidade própria, muito bem conhecida de seus leitores.

Também amplia sua abrangência. Os autores, além de poderem publicar na língua portuguesa, também terão a opção de submeter seus manuscritos em espanhol ou inglês, possibilitando, assim, a melhor divulgação de seus trabalhos entre pesquisadores de todo o mundo. Novos tempos exigem novos rumos.

Assim, agradecendo àqueles que ao longo desses 25 anos contribuíram com Infarma, convidamos a continuarem submetendo seus manuscritos ao Infarma - Ciências Farmacêuticas e estendemos esse convite às novas gerações de pesquisadores do Brasil e do mundo. 